\title{
The Role of Customer Perceived Value Mediates the Effect of Service Quality on Consumer Satisfaction
}

\section{Peran Customer Perceived Value Memediasi Pengaruh Kualitas Layanan Terhadap Kepuasan Konsumen}

\author{
A.A Ngr Wishrawan Bhaskara Warman ${ }^{1}$, Ni Made Purnami ${ }^{2}$ \\ ${ }^{1,2}$ Fakultas Eknomi dan Bisnis, Universitas Udayana \\ E-mail:madepurnami@unud.ac.id
}

\begin{abstract}
This study aims to determine the quality of service to customer satisfaction through the perceived value in Sing Ken Ken Lifestyle Boutique Hotel. This study used 130 respondents through purposive sampling method. Data collection methods used through questionnaires. Data analysis technique which is technique of path analysis and test of sobel. The results showed that the service quality is positive and significant on the perceived value of the customer, the service quality is positive and significant on customer satisfaction, the perceived value of the customer, and the perceived value of consumers as mediation of service quality to customer satisfaction. The results showed that the service quality and customers perceived value can affect consumer satisfaction and the perceived value consumers can mediate the effect of service quality to customer satisfaction.
\end{abstract}

Keywords : service quality, customer perceived value, customer satisfaction

\begin{abstract}
ABSTRAK
Penelitian ini bertujuan untuk menguji pengaruh kualitas layanan terhadap kepuasan konsumen melalui customer perceived value di Sing Ken Ken Lifestyle Boutique Hotel. Penelitian ini menggunakan sampel sebanyak 130 responden melalui metode purposive sampling. Metode Pengumpulan data yang digunakan melalui penyebaran kuesioner. Teknik analisis data yang digunakan adalah teknik analisis jalur (path analysis) dan uji sobel. Hasil analisis menunjukkan bahwa kualitas pelayanan berpengaruh positif dan signifikan pada customer perceived value, kualitas layanan berpengaruh positif dan signifikan pada kepuasan konsumen, customer perceived value berpengaruh positif dan signifikan pada kepuasan konsumen dan customer perceived value sebagai mediasi kualitas layanan terhadap kepuasan konsumen. Hasil temuan penelitian ini menunjukkan bahwa kualitas layanan dan customer perceived value dapat mempengaruhi kepuasan konsumen serta customer perceived value dapat memediasi pengaruh kualitas layanan terhadap kepuasan konsumen.
\end{abstract}

Kata kunci : kualitas layanan, customer perceived value, kepuasan konsumen

\section{PENDAHULUAN}

Pola pikir konsumen yang dinamis berpengaruh terhadap perkembangan bisnis jasa, hal tersebut dikarenakan konsumen mempunyai hak dalam memilih pelaku industri jasa dalam menawarkan produknya. Salah satu sektor industri yang memberikan kontribusi dan dampak bagi perekonomian di Bali adalah pariwisata. Pada kondisi persaingan yang semakin kompetitif ini, hanya perusahaan yang mempunyai wawasan dan mementingkan konsumen yang mampu bertahan dan unggul [1]. Perusahaan dalam menjalan usahanya yang pertama kali dilakukan adalah produk apa yang dapat dijual, berapa banyak yang dapat dijual, kemudian strategi apa yang akan digunakan dalam

Peran Customer Perceived Value Memediasi Pengaruh Kualitas Layanan Terhadap Kepuasan Konsumen / A.A Ngr Wishrawan Bhaskara Warman, Ni Made Purnami

Peer reviewed under responsibili of Universitas Muhammadiyah Sidoarjo.

(C) 2019 Universitas Muhammadiyah Sidoarjo. All Right reserved. This is an open access article

under the CC BY licence (http://creativecommons.org/licences/by/4.0/ ) 
Prozima, Vol 3, No.1, Juni 2019, 1-9

E. ISSN. 2541-5115

Journal Homepage: http://ojs.umsida.ac.id/index.php/prozima

DOI Link: http://doi.org/10.21070/prozima.v3i1.1300

Article DOI: http://doi.org/10.21070/prozima.v3i1.1300

menarik minat konsumen serta bersaing serta beradaptasi dengan perubahan pasar. Jasa merupakan setiap tindakan atau perbuatan yang ditawarkan oleh pihak satu ke pihak lain yang bersifat tangible (tidak berwujud fisik) dan tidak menghasilkan kepemilikan. Karakteristik jasa terdiri dari intangibility, separability, variability, perishability dan lack of ownership [2].

Bali merupakan salah satu pulau yang menjadi tujuan wisatawan untuk memanjakan diri mereka dan untuk melakukan pertemuan dengan rekan bisnis mereka seperti MICE (Meeting, Incentive, Conferencing, Exhibition). Kabupaten Badung merupakan salah satu daerah di Pulau Bali yang ramai dikunjungi oleh wisatawan. Badan Pusat Statistik (BPS) telah melakukan survei untuk mengetahui seberapa banyak tingkat kunjungan wisatawan ke Kabupaten Badung. Hasil survei menyatakan bahwa tingkat kunjungan wisatawan ke Kabupaten Badung tidak hanya mengalami peningkatan hingga mencapai 1.234 .843 , tingkat kunjungan wisatawan ke bali juga sempat mengalami penurunan hingga mencapai 437.778 .

Adanya peningkatan kunjungan wisatawan ke Bali, selain dikarenakan keindahan alam dan banyaknya pilijan obyek wisata adalah adat dan budaya masyarakat Bali. Sehingga, untuk mengatasi jumlah wisatawan yang berkunjung harus diselaraskan dan disesuaikan dengan fasilitasnya, yaitu penginapan (perhotelan). Kualitas layanan kepada konsumen menjadi hal yang sangat penting, karena hal ini berkorelasi dengan kepuasan konsumen (customer satisfaction) sehingga akan meningkatkan loyalitas konsumen [3].

Kepuasan konsumen merupakan salah satu indikator keberhasilan suatu perusahaan dalam memberikan pelayanan terkait produk yang dijual dan usaha yang dijalankan, hal ini karena dengan memuaskan konsumen maka perusahaan dapat meningkatkan keuntungan dan mendapatkan pangsa pasar yang luas [4]. Pemberian pelayanan yang terbaik bukanlah hal yang mudah bagi perusahaan di bidang jasa [5]. Tingkat kepuasan seorang konsumen itu sendiri dapat diperoleh dari perbandingan atas jenis pelayanan yang telah didapat oleh konsumen dengan jenis pelayanan yang diharapkan oleh konsumen. Kualitas layanan merupakan akar penting dalam memberikan kepuasan kepada konsumen denganhasil perilaku dari mulut ke mulut, keluhan, rekomendasi dan atau pertukaran atau perpindahan [6]. Kualitas layanan mempunyai lima dimendi, yaitu tangible (bukti fisik), reliability (kehandalan), responsiveness (daya tanggap), assurance (jaminan), dan empathy (empati) [7]. Apabila perusahaan menawarkan sebuah produk atau jasa dengan kualitas standar, tetapi biaya jauh lebih rendah dibandingkan dengan biaya-biaya industri, maka organisasi akan superior dalam biaya dan /atau harga. Perusahaan yang memiliki keunggulan biaya menyeluruh dapat memanfaatkan keunggulan ini untuk menetapkan harga rendah atau mengambil marjin laba yang lebih tinggi. Perusahaan yang mampu membuat produk dengan biaya yang lebih rendah, kemudian menjualnya dengan harga yang dapat memberikan laba yang lebih besar dibandingkan dengan pesainya [8].

Customer perceived value merupakan nilai yang dirasakan oleh konsumen sama atau lebih besar dari harapan dari konsumen. Customer perceived value merupakan perbedaan antara manfaat dan pengorbanan yang dipersepsikan [9]. Kepuasan konsumen merupakan penilaian emosional dari konsumen atas jasa yang diterima, dimana terpenuhinya antara harapan dan kebutuhan [4]. Jika konsumen menerima nilai yang lebih besar dari harapannya, maka secara tidak langsung akan menghasilkan kepuasan konsumen yang lebih tinggi. Kualitas layanan berhubungan positif dan signifikan terhadap perceived customer value, kepuasan konsumen dan minat mengunjungi ulang [10]. Perceived value adalah penilaian konsumen atas produk yang diterima dan diberikan [11]. Kualitas layanan menggerakkan customer perceived value konsumen [12].

Sing Ken Ken Lifestyle Boutique Hotel merupakan hotel kelas melati yang ada di Kabupaten Badung. Hotel ini beralamat di Jalan Arjuna No. 1, Legian Kaja, Kuta Bali. Sing Ken Ken Lifestyle Boutique Hotel, merupakan salah satu perusahaan hotel dari Indonesia. Singkenken di Bali dapat berarti "Tidak apa - apa" hal tersebut berarti ketika anda tiba di Singkenken Lifestyle Boutique Hotel anda tidak perlu khawatir tentang apa pun. Sing Ken Ken Lifestyle Boutique Hotel kini memiliki beberapa tipe kamar diantaranya terdapat 72 deluxe room, 3 family suite, 2 junior

Peran Customer Perceived Value Memediasi Pengaruh Kualitas Layanan Terhadap Kepuasan Konsumen / A.A Ngr Wishrawan Bhaskara Warman, Ni Made Purnami

Peer reviewed under responsibili of Universitas Muhammadiyah Sidoarjo.

(C) 2019 Universitas Muhammadiyah Sidoarjo. All Right reserved. This is an open access article

under the CC BY licence (http://creativecommons.org/licences/by/4.0/ ) 


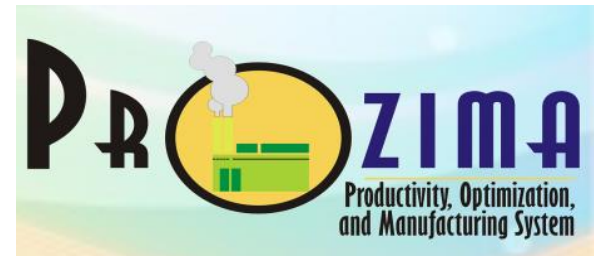

Prozima, Vol 3, No.1, Juni 2019, 1-9

E. ISSN. 2541-5115

Journal Homepage: http://ojs.umsida.ac.id/index.php/prozima

DOI Link: http://doi.org/10.21070/prozima.v3i1.1300

Article DOI: http://doi.org/10.21070/prozima.v3i1.1300

suite, dan 1 presidential suite. Fasilitas yang ditawarkan yaitu swimming pool, spa, gym, transportasi, restoran, dan room service.

Ketidak puasan konsumen dilihat dari semakin banyak keluhan yang diterima oleh hotel. Akibat ketidakpuasan tersebut maka akan berdampak buruk terhadap citra hotel. Sehingga untuk mengurangi keluhan konsumen, maka salah satu yang harus dilakukan adalah perbaikan kualitas layanan hotel kepada konsumen. Hal tersebut dikarenakan banyaknya pesaing usaha disektor yang sama yaitu menyediakan hotel sebagai penginapan dalam memberikan kualitas layanan yang terbaik sehingga akan menarik konsumen untuk menggunakan jasa mereka. Hipotesa yang digunakan dalam penelitian ini adalah:

$\begin{array}{ll}\mathrm{H}_{1} & \text { : Kualitas layanan berpengaruh positif dan signifikan terhadap customer perceived value } \\ \mathrm{H}_{2} & \text { : Kualitas layanan berpengaruh positif dan signifikan terhadap kepuasan konsumen. } \\ \mathrm{H}_{3} & \text { : Customer perceived value berpengaruh positif dan signifikan terhadap kepuasan konsumen } \\ \mathrm{H}_{4} & \text { : Customer Perceived Value memediasi Kualitas layanan terhadap Kepuasan Konsumen }\end{array}$

\section{METODE}

Lokasi penelitian dilakukan di Sing Ken Ken Lifestyle Boutique Hotel. Populasi dalam penelitian ini adalah tamu yang sudah pernah menginap di Sing Ken Ken Lifestyle Boutique Hotel, dengan jumlah 130 responden. Jadi responden yang diambil sebanyak 130 orang responden.

Variabel Endogen pada penelitian ini adalah Kepuasan Konsumen (Y2). Variabel Mediasi pada penelitian ini adalah Customer perceived value(Y1) dan variabel Eksogen dalam penelitian ini adalah Kualitas layanan (X).

Tabel 1. Indikator Variabel Penelitian.

\begin{tabular}{|c|c|c|}
\hline Variabel & Indikator & Sumber \\
\hline Kualitas layanan (X) & $\begin{array}{l}\text { 1. Penampilan fasilitas fisik perusahaan } \\
\text { (tangibility) (X.1) } \\
\text { 2. Penanganan membantu pelanggan } \\
\text { (Emphaty) (X.2) } \\
\text { 3. Penanganan membantu konsumen } \\
\text { (responsiveness) (X.3) } \\
\text { 4. Kehandalan melayani konsumen } \\
\text { (reliability) (X.4) } \\
\text { 5. Jaminan (assurance)(X.5) }\end{array}$ & Tjiptono (2014:282) \\
\hline Customer perceived value $(\mathrm{Y} 1)$ & $\begin{array}{l}\text { 1. Memberikan nilai tambah (Y1.1) } \\
\text { 2. Layak membayar lebih (Y1.2) } \\
\text { 3. Dapat memenuhi kebutuhan(Y1.3) } \\
\text { 4. Memberikan keuntungan yang lebih besar } \\
\text { dibandingkan biaya (Y1.4) }\end{array}$ & Wu dan Chen (2014) \\
\hline Kepuasan Konsumen (Y2) & $\begin{array}{l}\text { 1. Pelayanan (Y2.1) } \\
\text { 2. Kualitas Produk (Y2.2) } \\
\text { 3. Harga (Y2.3) } \\
\text { 4. Promosi (Y2.4 }\end{array}$ & Amir (2012) \\
\hline
\end{tabular}

Metode penentuan sampel yang digunakan pada penelitian ini adalah non probability sampling dengan metode purposive sampling. Analisis jalur digunakan untuk menentukan pola hubungan antara tiga atau lebih dan tidak dapat digunakan untuk mengkonfirmasi atau menolak hipotesis.Dasar perhitungan koefisien jalur adalah analisis korelasi dan regresi dan dalam perhitungan menggunakan software dengan program SPSS forwindows.

Peran Customer Perceived Value Memediasi Pengaruh Kualitas Layanan Terhadap Kepuasan Konsumen / A.A Ngr Wishrawan Bhaskara Warman, Ni Made Purnami

Peer reviewed under responsibili of Universitas Muhammadiyah Sidoarjo.

(C) 2019 Universitas Muhammadiyah Sidoarjo. All Right reserved. This is an open access article

under the CC BY licence (http://creativecommons.org/licences/by/4.0/ ) 


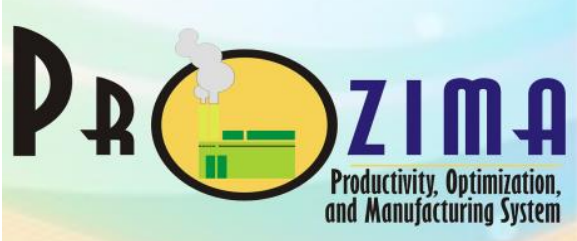

Prozima, Vol 3, No.1, Juni 2019, 1-9

E. ISSN. 2541-5115

Journal Homepage: http://ojs.umsida.ac.id/index.php/prozima

DOI Link: http://doi.org/10.21070/prozima.v3i1.1300

Article DOI: http://doi.org/10.21070/prozima.v3i1.1300

HASIL DAN PEMBAHASAN

Pengujian data dalam penelitian ini mengunakan teknik analisis jalur (path analysis), dimana analisis jalur adalah perluasan dari analisis regresi linear berganda untuk menguji hubungan kualitas antara 2 atau lebih variabel.

Tabel 2. Hasil Analisis Regresi Linier Substruktur I

\begin{tabular}{llrrrrrr}
\hline & & \multicolumn{7}{c}{$\begin{array}{c}\text { Standardized } \\
\text { Unstandardized Coefficients } \\
\text { Model }\end{array}$} & B & Std. Error & Beta & \multicolumn{1}{c}{ t } & \multicolumn{1}{c}{ Sig. } \\
\hline 1 & (Constant) & 9.166 & 1.304 & & 7.027 & .000 \\
& kualitas.pelayanan & .329 & .069 & .390 & 4.788 & .000 \\
\hline
\end{tabular}

Sumber: Data diolah, 2018

Berdasarkan Tabel 2 diatas, maka persamaan strukturalnya adalah sebagai berikut :

$$
\begin{aligned}
& \mathrm{Y}_{1}=\beta_{1} \mathrm{X}+\varepsilon_{1} \\
& \mathrm{Y}_{1}=0,390 \mathrm{X}
\end{aligned}
$$

Nilai $\beta_{1}$ adalah sebesar 0,390 memiliki arti bahwa kualitas layanan berpengaruh positif terhadap customer perceived value, dengan kata lain jika faktor kualitas layanan meningkat maka akan mengakibatkan peningkatan pada customer perceived value.

Tabel 3. Hasil Analisis Regresi Linier Substruktur II

\begin{tabular}{cccccc}
\hline Model & $\begin{array}{c}\text { Unstandard } \\
\text { ized } \\
\text { Coefficients } \\
\text { B } \begin{array}{c}\text { Std.Err } \\
\text { or }\end{array}\end{array}$ & $\begin{array}{c}\text { Standardized } \\
\text { Coefficients }\end{array}$ & Beta & & Sig. \\
\cline { 3 - 6 } & & & & \\
\cline { 5 - 6 } & .482 & 1.393 & & .346 & .730 \\
1 (Constant) Kualitas layanan & .517 & .068 & .536 & 7.637 & .000 \\
Customer Perceived value & .305 & .080 & .267 & 3.808 & .000 \\
\hline R1 Square & & & & & 0,470 \\
F Statistik & & & & & 56,302 \\
Signifikansi & & & & & 0,000 \\
\hline
\end{tabular}

Sumber : Data diolah, 2018

Berdasarkan hasil olah data diatas, maka persamaan strukturalnya adalah sebagai berikut:

$$
\begin{aligned}
& \mathrm{Y}_{2}=\beta_{2} \mathrm{X}+\beta_{3} \mathrm{Y} 1+\varepsilon_{2} . \\
& \mathrm{Y}_{2}=0,536 \mathrm{X}+0,267 \mathrm{Y} 1
\end{aligned}
$$

Berdasarkan persamaan tersebut maka dapat disimpulkan bahwa nilai $\beta_{2}$ adalah sebesar 0,536 memiliki arti bahwa kualitas layanan berpengaruh positif terhadap kepuasan konsumen, dengan kata lain jika faktor kualitas layanan meningkat maka akan mengakibatkan peningkatan pada kepuasan konsumen Sing Ken Ken Lifestyle Boutique Hotel.

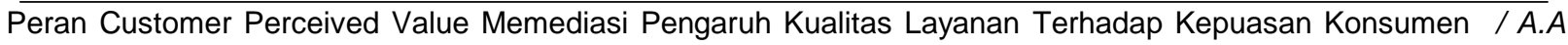
Ngr Wishrawan Bhaskara Warman, Ni Made Purnami

Peer reviewed under responsibili of Universitas Muhammadiyah Sidoarjo.

(C) 2019 Universitas Muhammadiyah Sidoarjo. All Right reserved. This is an open access article

under the CC BY licence (http://creativecommons.org/licences/by/4.0/ ) 


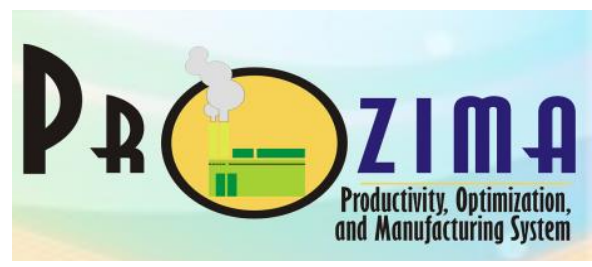

Prozima, Vol 3, No.1, Juni 2019, 1-9

E. ISSN. 2541-5115

Journal Homepage: http://ojs.umsida.ac.id/index.php/prozima

DOI Link: http://doi.org/10.21070/prozima.v3i1.1300

Article DOI: http://doi.org/10.21070/prozima.v3i1.1300

Nilai $\beta_{3}$ adalah sebesar 0,267 memiliki arti bahwa customer perceived value berpengaruh positif terhadap kepuasan konsumen, dengan kata lain jika faktor customer perceived value meningkat maka akan mengakibatkan peningkatan pada kepuasan konsumen Sing Ken Ken Lifeyle Boutique Hotel.

Tabel 4. Pengaruh Langsung dan Pengaruh Tidak Langsung serta Pengaruh Total Kualitas layanan (X), Customer Perceived Value $\left(\mathrm{Y}_{1}\right)$, dan Kepuasan Konsumen $\left(\mathrm{Y}_{2}\right)$

\begin{tabular}{cccc}
\hline $\begin{array}{c}\text { Pengaruh } \\
\text { Variabel }\end{array}$ & $\begin{array}{c}\text { Pengaruh } \\
\text { Langsung }\end{array}$ & $\begin{array}{c}\text { Pengaruh Tidak Langsung Melalui } \\
\text { Customer Perceived Value } \\
\left(\boldsymbol{\beta}_{\mathbf{2}} \mathbf{x} \boldsymbol{\beta}_{\mathbf{3}}\right)\end{array}$ & Pengaruh Total \\
\hline $\mathrm{X} \rightarrow \mathrm{Y}_{1}$ & 0,390 & - & 0,390 \\
$\mathrm{X} \rightarrow \mathrm{Y}_{2}$ & 0,536 & 0,1041 & 0,6401 \\
$\mathrm{Y}_{1} \rightarrow \mathrm{Y}_{2}$ & 0,267 & - & 0,267 \\
\hline \multicolumn{2}{l}{ Sumber : Data Diolah, 2018}
\end{tabular}

Hasil pada Tabel 4 menunjukan bahwa pengaruh langsung variabel kualitas layanan terhadap kepuasan konsumen memiliki nilai koefisien beta sebesar 0,536 namun pengaruh tidak langsung yang dimediasi oleh customer perceived value menunjukan nilai koefisien beta sebesar 0,1041 . Ini membuktikan bahwa customer perceived value memediasi kualitas layanan terhadap kepuasan konsumen dengan pengaruh total yang diperoleh adalah sebesar 0,6401 .

\section{Pengaruh Kualitas Layanan Terhadap Customer Percieved Value}

Pengujian hipotesis pada pengaruh kualitas layanan terhadap customer perceived value menunjukkan bahwa kualitas layanan secara signifikan berpengaruh positif terhadap customer perceived value. Hasil tersebut menunjukan semakin baiknya kualitas layanan yang diberikan oleh Sing Ken Ken Lifestyle Boutique Hotel maka akan meningkatkan costumer perceived value dari konsumen Sing Ken Ken Lifestyle Boutique Hotel.

Hasil penelitian ini menjelaskan bahwa kualitas layanan berpengaruh positif dan signifikan terhadap customer perceived value [10]. Hal ini menunjukan jika kualitas layanan yang ditawarkan semakin baik maka customer perceived value akan meningkat juga.

\section{Pengaruh Kualitas Layanan Terhadap Kepuasan Konsumen}

Pengujian hipotesis pada pengaruh kualitas layanan terhadap kepuasan konsumen menunjukkan bahwa kualitas layanan secara signifikan berpengaruh positif terhadap kepuasan konsumen. Hal tersebut menunjukan semakin baiknya kualitas layanan yang diberikan oleh Sing Ken Ken Lifestyle Boutique Hotel maka akan meningkatkan kepuasan konsumen Sing Ken Ken Lifestyle Boutique Hotel.

Hasil penelitian ini mendukung temuan yang menjelaskan bahwa kualitas layanan berpengaruh positif dan signifikan terhadap kepuasan konsumen. Hal ini menunjukan bahwa kualitas layanan merupakan salah satu faktor yang harus diperhatikan dalam meningkatkan kepuasan konsumen.

\section{Pengaruh Customer Perceived Valuei Terhadap Kepuasan Konsumen}

Pengujian hipotesis pada pengaruh customer perceived value terhadap kepuasan konsumen menunjukkan bahwa customer perceived value secara signifikan berpengaruh positif terhadap kepuasan konsumen. Hal tersebut menunjukan semakin baiknya customer perceived value dalam benak konsumen maka kepuasan konsumen terhadap jasa Sing Ken Ken Lifestyle Boutique Hotel semakin meningkat.

Peran Customer Perceived Value Memediasi Pengaruh Kualitas Layanan Terhadap Kepuasan Konsumen / A.A Ngr Wishrawan Bhaskara Warman, Ni Made Purnami

Peer reviewed under responsibili of Universitas Muhammadiyah Sidoarjo.

(C) 2019 Universitas Muhammadiyah Sidoarjo. All Right reserved. This is an open access article

under the CC BY licence (http://creativecommons.org/licences/by/4.0/ ) 
Hasil penelitian ini mendukung temuan yang menjelaskan bahwa customer perceived value berpengaruh positif dan signifikan terhadap kepuasan konsumen[11]. Hal ini menunjukan bahwa semakin baik customer perceived value yang diberikan Sing Ken Ken Lifestyle Boutique Hotel maka dapat meningkatkkan kepuasan konsumen.

\section{Peran Customer Perceived Value Dalam Memediasi Kualitas Layanan Terhadap Kepuasan Konsumen}

Pengujian hipotesis pada peran customer perceived value dalam memediasi kualitas layanan terhadap kepuasan konsumen menunjukkan bahwa customer perceived value mampu memediasi pengaruh kualitas layanan terhadap kepuasan konsumen. Hal ini menunjukan customer perceived value memediasi pengaruh kualitas layanan terhadap kepuasan konsumen secara parsial, dengan kata lain customer perceived value memperkuat pengaruh kualitas layanan terhadap kepuasan konsumen yang semula bernilai 0,1041 namun setelah adanya customer perceived value sebagai variabel mediasi pengaruh kualitas layanan terhadap kepuasan konsumen meningkat menjadi 0,640 .

Berdasarkan model substruktur 1 dan substruktur 2, maka dapat disusun model diagram jalur akhir. Sebelum menyusun model diagram jalur akhir, terlebih dahulu dihitung nilai standar error sebagai berikut:(1)

$$
\begin{gathered}
\mathrm{Pe}_{\mathrm{i}}=\sqrt{1-\mathrm{R}_{1}^{2}} \ldots \ldots \\
\mathrm{Pe}_{1}=\sqrt{1-R_{1}^{2}}=\sqrt{1-0,152}=0,848 \\
\mathrm{Pe}_{2}=\sqrt{1-R_{2}^{2}}=\sqrt{1-0,472}=0,726
\end{gathered}
$$

Berdasarkan perhitungan pengaruh error (Pei), didapatkan hasil pengaruh error $\left(\mathrm{Pe}_{1}\right)$ sebesar 0,848 dan pengaruh error $\left(\mathrm{Pe}_{2}\right)$ sebesar 0,726. Hasil koefisien determinasi total adalah sebagai berikut:

$$
\begin{aligned}
& \mathrm{R}^{2}{ }_{\mathrm{m}}=1-\left(\mathrm{Pe}_{1}\right)^{2}\left(\mathrm{Pe}_{2}\right)^{2} \\
&=1-(0,848)^{2}(0,726)^{2} \\
&=1-(0,719)(0,527) \\
&=1-0,379=0,621
\end{aligned}
$$

Nilai determinasi total sebesar 0,621 mempunyai arti bahwa sebesar $62,1 \%$ variasi kepuasan konsumen dipengaruhi oleh variasi kualitas layanan dan customer perceived value, sedangkan sisanya sebesar $37,9 \%$ djelaskan oleh faktor lain yang tidak dimasukkan ke dalam model.

Uji sobel merupakan alat analisis yang digunakan untuk menguji signifikansi dari hubungan tidak langsung antara variabel independen dengan variabel dependen yang dimediasi oleh variabel mediator. Uji Sobel dirumuskan dengan persamaan berikut dan dapat dihitung dengan menggunakan aplikasi Microsoft Excel 2007. Uji sobel dihitung dengan rumus sebagai berikut:

$$
Z=\frac{a b}{\sqrt{b^{2} s_{a}^{2}+a^{2} s_{b}^{2}+s_{a}^{2} s_{b}^{2}}} \ldots
$$

$\operatorname{Sig}=(1-\operatorname{NORMDIST}(\mathrm{Z}))+2))$

Keterangan:

$$
\begin{aligned}
& \mathrm{a} \quad=0,390 \\
& \mathrm{~s}_{\mathrm{a}}=0,069 \\
& \mathrm{~b} \quad=0,267 \\
& \mathrm{~s} \mathrm{~b}=0,080 \quad 0,390.0,267 \\
& Z=\frac{\sqrt{0,267^{2} 0,069^{2}+0,390^{2} 0,080^{2}+0,069^{2} 0,080^{2}}}{}
\end{aligned}
$$

Peran Customer Perceived Value Memediasi Pengaruh Kualitas Layanan Terhadap Kepuasan Konsumen / A.A Ngr Wishrawan Bhaskara Warman, Ni Made Purnami

Peer reviewed under responsibili of Universitas Muhammadiyah Sidoarjo.

(C) 2019 Universitas Muhammadiyah Sidoarjo. All Right reserved. This is an open access article under the CC BY licence (http://creativecommons.org/licences/by/4.0/ ) 


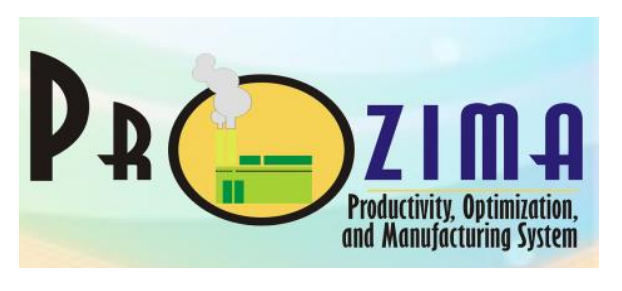

Prozima, Vol 3, No.1, Juni 2019, 1-9

E. ISSN. 2541-5115

Journal Homepage: http://ojs.umsida.ac.id/index.php/prozima

DOI Link: http://doi.org/10.21070/prozima.v3i1.1300

Article DOI: http://doi.org/10.21070/prozima.v3i1.1300

$$
\begin{aligned}
& Z=\frac{0,1041}{\sqrt{0,0034+0,0010+0,0000}} \\
& Z=\frac{0,1041}{0,03665} \\
& Z=2,8411
\end{aligned}
$$

Tabel 5. Hasil Uji Sobel

\begin{tabular}{ccc}
\hline Sobel & Nilai & Keterangan \\
\hline $\mathrm{Z}$ & 28,411 & Memediasi \\
Sig. & 0,000 & Signifikansi \\
\hline
\end{tabular}

Sumber : Data diolah, 2018

Hasil dari pengujian variabel mediasi pada Tabel 5. yaitu customer perceived value didapatkan $\mathrm{Z}$ hitung sebesar 2,8411>1,96 dengan tingkat signifikan sebesar 0,000<0.05 yang berarti H0 ditolak dan $\mathrm{H} 1$ diterima yang berarti variabel customer perceived value dinilai secara signifikan memediasi variabel kualitas layanan pada kepuasan konsumen di Sing Ken Ken Lifestyle Boutique Hotel.

Implikasi teoritis dalam penelitian ini berhubungan dengan kontribusinya bagi perkembangan konsep dalam bidang ilmu pemasaran. Hasil temuan penelitian ini memperkuat penelitian-penelitian sebelumnya yang menunjukkan bahwa kualitas layanan dan customer perceived value dapat mempengaruhi kepuasan konsumen serta customer perceived value dapat memediasi kualitas layanan terhadap kepuasan konsumen.

Variabel kualitas layanan, dan customer perceived value berpengaruh positif dan signifikan terhadap kepuasan konsumen Sing Ken Ken Lifestyle Boutique Hotel serta customer perceived value mampu memediasi kualitas layanan terhadap kepuasan konsumen di Sing Ken Ken Lifestyle Boutique Hotel. Untuk variabel kualitas layanan, Sing Ken Ken Lifestyle Boutique Hotel sebagai perusahaan yang bergerak dalam bidang jasa perlu meningkatkan kualitas layanan yang dimilikinya dimana dengan meningkatkan kualitas layanan hotel akan menambahkan citra perusahaan yang dimilikinya dibandingkan pesaing lainnya serta dapat meningkatkan customer perceived value yang dapat mempengaruhi kepuasan konsumen. Kualitas layanan yang baik dapat mempengaruhi kepuasan konsumen setelah merasakan jasa yang diberikan pihak Sing Ken Ken Lifestyle Boutique Hotel bila mampu memenuhi kebutuhan yang diperlukan oleh konsumen.

Variabel customer perceived value merupakan variabel yang perlu diperhatikan oleh Sing Ken Ken Lifestyle Boutique Hotel karena dapat mempengaruhi kepuasan konsumen dan memediasi kualitas layanan terhadap kepuasan konsumen. Sing Ken Ken Lifestyle Boutique Hotel perlu meningkatkan customer perceived value yang diberikan kepada konsumen agar kesan yang tertanam dibenak konsumen baik dan dapat menigkatkan kepuasan konsumen. Ketiga variabel yang diteliti memiliki keterkaitan sata sama lain sehingga Sing Ken Ken Lifestyle Boutique Hotel perlu meningkatkan kualitas layanannya serta tetap menjaga customer perceived value agar kesan yang tertanam dibenak konsumen tetap baik sehingga dapat lebih meningkatkan kepuasan konsumen.

Ruang lingkup penelitian hanya terbatas pada satu hotel yaitu Sing Ken Ken Lifestyle Boutique Hotel dengan jumlah sampel sebanyak 130 orang, sehingga hasil penelitian ini tidak dapat digeneralisasi dalam lingkup yang lebih luas. Penelitian ini hanya meneliti peran customer perceived value memediasi pengaruh kualitas layanan terhadap kepuasan konsumen di Sing Ken Ken Lifestyle Boutique Hotel, sedangkan masih banyak faktor yang mempengaruhi kepuasan konsumen misalnya kualitas produk, sehingga penelitian ini penting untuk dilakukan kembali.

Peran Customer Perceived Value Memediasi Pengaruh Kualitas Layanan Terhadap Kepuasan Konsumen / A.A Ngr Wishrawan Bhaskara Warman, Ni Made Purnami

Peer reviewed under responsibili of Universitas Muhammadiyah Sidoarjo.

(C) 2019 Universitas Muhammadiyah Sidoarjo. All Right reserved. This is an open access article

under the CC BY licence (http://creativecommons.org/licences/by/4.0/ ) 
Prozima, Vol 3, No.1, Juni 2019, 1-9

E. ISSN. 2541-5115

Journal Homepage: http://ojs.umsida.ac.id/index.php/prozima

DOI Link: http://doi.org/10.21070/prozima.v3i1.1300

Article DOI: http://doi.org/10.21070/prozima.v3i1.1300

\section{SIMPULAN}

Simpulan yang dapat diberikan berdasarkan pembahasan hasil penelitian yang telah dilakukan yaitu kualitas layanan secara signifikan berpengaruh positif terhadap customer perceived value di Sing Ken Ken Lifestyle Boutique Hotel. Hal tersebut menyimpulkan semakin baiknya kualitas layanan yang diberikan oleh Sing Ken Ken Lifestyle Boutique Hotel semakin baik maka akan meningkatkan customer perceived value .

Kualitas layanan secara signifikan berpengaruh positif terhadap kepuasan konsumen di Sing Ken Ken Lifestyle Boutique Hotel. Hal tersebut menyimpulkan bila kualitas layanan yang diberikan Sing Ken Ken Lifestyle Boutique Hotel sebanding atau bahkan melebihi harapan konsumen maka akan meningkatkan kepuasan konsumen Customer perceived value secara signifikan berpengaruh positif terhadap kepuasan konsumen di Sing Ken Ken Lifestyle Boutique Hotel. Hal tersebut menyimpulkan semakin baiknya customer perceived value yang diberikan terhadap konsumen maka akan meningkatkan kepuasan konsumen.

Customer perceived value mampu memediasi pengaruh kualitas layanan terhadap kepuasan konsumen di Sing Ken Ken Lifestyle Boutique Hotel. Hal tersebut menyimpulkan bahwa customer perceived value memediasi pengaruh kualitas layanan terhadap kepuasan konsumen secara parsial, dengan kata lain customer perceived value memperkuat pengaruh kualitas layanan terhadap kepuasan konsumen di Sing Ken Ken Lifestyle Boutique Hotel.

Saran yang dapat diberikan berdasarkan kesimpulan yang didapat adalah pihak Sing Ken Ken Lifestyle Boutique Hotel sebaiknya lebih meningkatkan kualitas layanan terutama dalam kemapuan perusahaan dan stafnya untuk dapat memenuhi harapan dan kepuasan konsumen. Hal yang dapat dilakukan Sing Ken Ken Lifestyle Boutique Hotel adalah menjalin hubungan yang kuat dengan konsumen, ikatan yang baik dengan konsumen memungkinkan perusahaan untuk memahami dengan seksama harapan serta kebutuhan konsumen.

Pihak Sing Ken Ken Lifestyle Boutique Hotel sebaiknya lebih meningkatkan produk yang di tawarkan kepada konsumen. Penilaian konsumen terhadap utilitas suatu produk adalah berdasarkan persepsi mengenai apa yang diterima dan apa yang diberikan, sehingga customer perceived value merupakan trade off antara pengorbanan dan manfaat komponen suatu produk yang berkaitan dengan pengorbanan yang dibuat oleh konsumen.

\section{DAFTAR PUSTAKA}

[1] I. W. W. Suryadharma and I. K. Nurcaya, "Pengaruh Kualitas layanan pada Kepuasan Pelanggan Hotel Bintang Pesona Di Denpasar Timur," E-Jurnal Manaj. Univ. Udayana, vol. 4, no. 4, pp. 930-942, 2015.

[2] K. Keller, Marketing Managemnent Edisi 14, Global. Pearson Prentice Hall, 2012.

[3] G. Gantara, S. Kumadji, and E. Yulianto, "Analisis Pengaruh Kualitas layanan dan Customer Perceived Value Terhadap Kepuasan Pelanggan dan Loyalitas Pelanggan (Studi Empiris pada Mahasiswa Universitas Brawijaya Malang Pengguna Kartu Seluler IM3,”J. Admistrasi Bisnis, vol. 1, no. 1, pp. 40-48, 2013.

[4] I. Setyobudi and Daryanto, Konsumen dan Pelayanan Prima. Yogyakarta: Gava Media, 2014.

[5] N. Gonius, "Studi Deskriptif Tentang Costumer Complaints di Restoran Wok Noodles di Galaxy Mall Surabaya," J. Ilm. Mhs., vol. 2, no. 1, pp. 1-15, 2013.

[6] U. Yavas, M. Benkenstein, and U. Stuhldreier, "Relationship Between Service Quality and Behavoiral Outcomes: AStudy of Private Bank Customers In Germany," Int. J. Bank Mark., vol. 22, no. 2, pp. 144-157, 2004.

[7] L. Christopher, Pemasaran Jasa. Jakarta: Erlangga, 2010.

[8] K. D. N. E. Widjajanti, "Analisis Pengaruh Kualitas layanan Terhadap Kepuasan Pelanggan Di Warnet Usm," J. Din. Sosbud, vol. 14, no. 1, 2012.

[9] S. R. H. Rahab and A. T. Nawarini, "Peran Customer Perceived Value dan Kepuasan Pelanggan Dalam Upaya Membangun Loyalitas Pengguna Kartu Seluler,” E-Jurnal UNTAG Semarang, vol. 30, no. 1, pp. 7684, 2015.

[10] R. Muhammad, A. N. Sidiqquei, H. M.Awan, and K. Bukhari, "Relationship Between Service Quality, Customer perceived value, Satisfaction And Revisit Intention in Hotel Industry," Interdisclipinary J. Contemp. Res. Bus., vol. 4, no. 8, pp. 788-805, 2012.

[11] L. L. Tung, "Service Quality and Perceived Value's Impact on Satisfaction, Intention and Usage of Short Peran Customer Perceived Value Memediasi Pengaruh Kualitas Layanan Terhadap Kepuasan Konsumen / A.A Ngr Wishrawan Bhaskara Warman, Ni Made Purnami

Peer reviewed under responsibili of Universitas Muhammadiyah Sidoarjo.

(C) 2019 Universitas Muhammadiyah Sidoarjo. All Right reserved. This is an open access article

under the CC BY licence (http://creativecommons.org/licences/by/4.0/) 
Prozima, Vol 3, No.1, Juni 2019, 1-9

E. ISSN. 2541-5115

Journal Homepage: http://ojs.umsida.ac.id/index.php/prozima

DOI Link: http://doi.org/10.21070/prozima.v3i1.1300

Article DOI: http://doi.org/10.21070/prozima.v3i1.1300

Message Service (SMS)," Inf. Syst. Front., vol. 6, pp. 353-368, 2004.

[12] G. Howat and G. Assaker, "The Hierarchical Effects of Perceived Quality on Customer Perceived Value, Satisfaction, and Loyalty: Empirical Results From Public, Outdoor Aquatic Centres in Australia," Sport Manag. Rev. Elsevier J., vol. 16, no. 3, pp. 268-284, 2013.

Peran Customer Perceived Value Memediasi Pengaruh Kualitas Layanan Terhadap Kepuasan Konsumen / A. $A$ Ngr Wishrawan Bhaskara Warman, Ni Made Purnami

Peer reviewed under responsibili of Universitas Muhammadiyah Sidoarjo.

(C) 2019 Universitas Muhammadiyah Sidoarjo. All Right reserved. This is an open access article under the CC BY licence (http://creativecommons.org/licences/by/4.0/ ) 